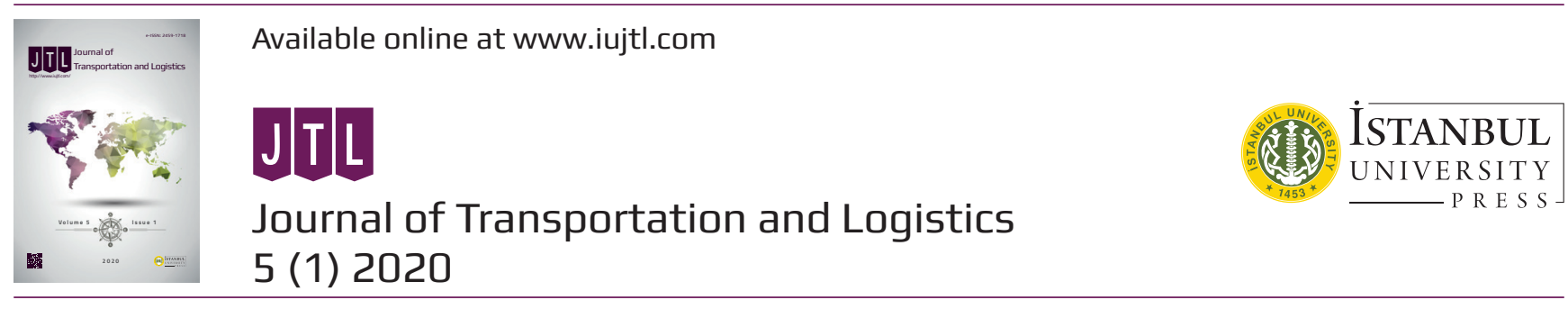

\title{
Using Data Envelopment Analysis for Measuring the Efficiency of Water Bottling Distributors
}

\author{
Veri Zarflama Analizini Yöntemi Kullanarak Su Distribütörlerinin Etkinliğinin \\ Ölçümlenmesi
}

\author{
Uğur Arcagök ${ }^{1}$ []
}

\begin{abstract}
The purpose of this research is to assess the efficiency and productivity of 51 water bottling distributors based on DEA (Data Envelopment Analysis) approaches that were evaluated between 2012 and 2013, as per 5 variables, these being sales, staff, distance, size, and capex. We got different results from the initial assumptions after the analysis. Big cities distributors' efficiencies are better than the small cities and town distributors. The time period was selected because of the global conflict, war in Syria, Turkish government policies, accepting the war refugees and the other reasons, natural and environmental. According to the research results, some suggestions have been made for the managers of the distributors. Keywords: Data envelopment analysis, Productivity analysis, Malmquist index, Efficiency change, Total factor productivity
\end{abstract}

öz

Bu araştırmanın amacı, bir su fabrikasının 51 tane dağıııcııının 2012 ve 2013 yılları arasındaki verilerini 5 farklı değişken (satışlar, personel sayısı, firma ile dağıııcı arasındaki uzaklık, depo büyüklüğü ve diğer kuruluş maliyetleri) yardımıyla Veri Zarflama Analizi yöntemi (VZA) kullanarak dağıtıcıların etkinliğini ve verimliliği değerlendirmektir. Analizden sonra ilk varsayımlardan farklı sonuçlar aldık. Büyük şehirlerin distribütörlerinin verimliliği küçük şehirlerden ve kasaba distribütörlerinden daha iyi olduğu sonucuna varıldı. Küresel çatışma, Suriye'deki savaş, Türk hükümeti politikaları, savaş mültecilerini kabul etme ve diğer doğal ve çevresel nedenlerden dolayı 2012 ve 2013 yılları seçildi. Analiz sonuçlarına göre dağıtıcıların yöneticilerine etkinliklerini ve verimliliklerini artıııı bazı önerilerde bulunuldu.

Anahtar Kelimeler: Data envelopment analysis, Productivity analysis, Malmquist index, Efficiency change, Total factor productivity

1 Corresponding author: Uğur Arcagök / Istanbul University Faculty of Business Administration, Department of Quantitative Methods, İstanbul, Turkey E-mail: ugurarcagok@istanbul.edu.tr, ORCID: 0000-0002-4469-9525

Citation: Arcagok, U. (2020). Using Data Envelopment Analysis for Measuring the Efficiency of Water Bottling Distributors. Journal of Transportation and Logistics, 5(1), 55-81. https://doi.org/10.26650/JTL.2020.0007 


\section{Introduction}

In the research, the efficiency of 51 distributors was assessed based on Data Envelopment Analysis (DEA) approaches that had been evaluated between 2012 and 2013, as per 5 variables, these being sales, staff, distance, size, and capex.

The most important and reasonable step in the DEA analysis is to figure out variables, inputs and outputs. Then, the variables are explained through specific statistical analyses (descriptive statistical analysis, correlation analysis, and box Plot graph analysis). The second step is the analysis of the Data Envelopment Analysis (DEA). Furthermore, the most convenient orientation model is arranged. In other words, the main objective is to focus on the orientation model of inputs or outputs. Then, scale efficiency (CRS or VRS) is defined through explanations. The scale efficiency gives specific information relevant to the distributors. Moreover, the allocative efficiency of the distributors is explained as the cost function. Also, the Malmquist Index of the distributors is examined. Consequently, some assumptions are made such as the output of total factor productivity analysis according to the data collected in the recent two years such as the Malmquist index (MI), the efficiency change (EC), and the technological change (TC) for every decision-making unit (DMU).

Briefly, it would be better to explain the most appropriate conceptual model before the analysis. For this reason, the inputs and outputs, the orientation model, and returns to scale (VRS or CRS) should be identified before the analysis. After stating the result of the analysis, they are studied on Pim-Dea, Stata, Spss and Microsoft Excel computer programs.

\subsection{Background Information About the Establishment}

The establishment is a natural spring water factory that had been founded in Turkey in 2006, and it has 51 distributors in Turkey. The product line of the company covers the following products: natural spring water bottles of $0.5 \mathrm{~L}, 1.5 \mathrm{~L}, 5 \mathrm{~L}$, and $19 \mathrm{~L}$. All the products are bottled in a zero-touch environment. The natural spring waters have a high reputation in Turkey, and thus, this might have created a positive effect on sales and advertisement.

The distributors' main role and objective is to make distinction between the packages as per shops, restaurants, hospitals, universities, schools etc.; and this helps to cover a variety of customers, and thus, keeps the business steadily profitable. The most important responsibilities are implementing a strong stock control system, and "just in time" delivery to the customers. Although a few distributors are big such as the ones in the Diyarbakir, Batman, Gaziantep, Şanlıurfa and Mardin Provinces, most of the distributors are relatively small. With the use of the data obtained from the distributors in between 2012 and 2013, the research examined their relative efficiency, and simultaneously tested the distributors by the efficiency evaluation methods through returns to scale considering a sample of 51 distributors of the water factory.

The supply chain of the company begins with the suppliers of raw materials of components such as caps, plastic bottles and labels. The procurement department is responsible for the suppliers. Then, the raw materials are sent to the manufacturing process. The 


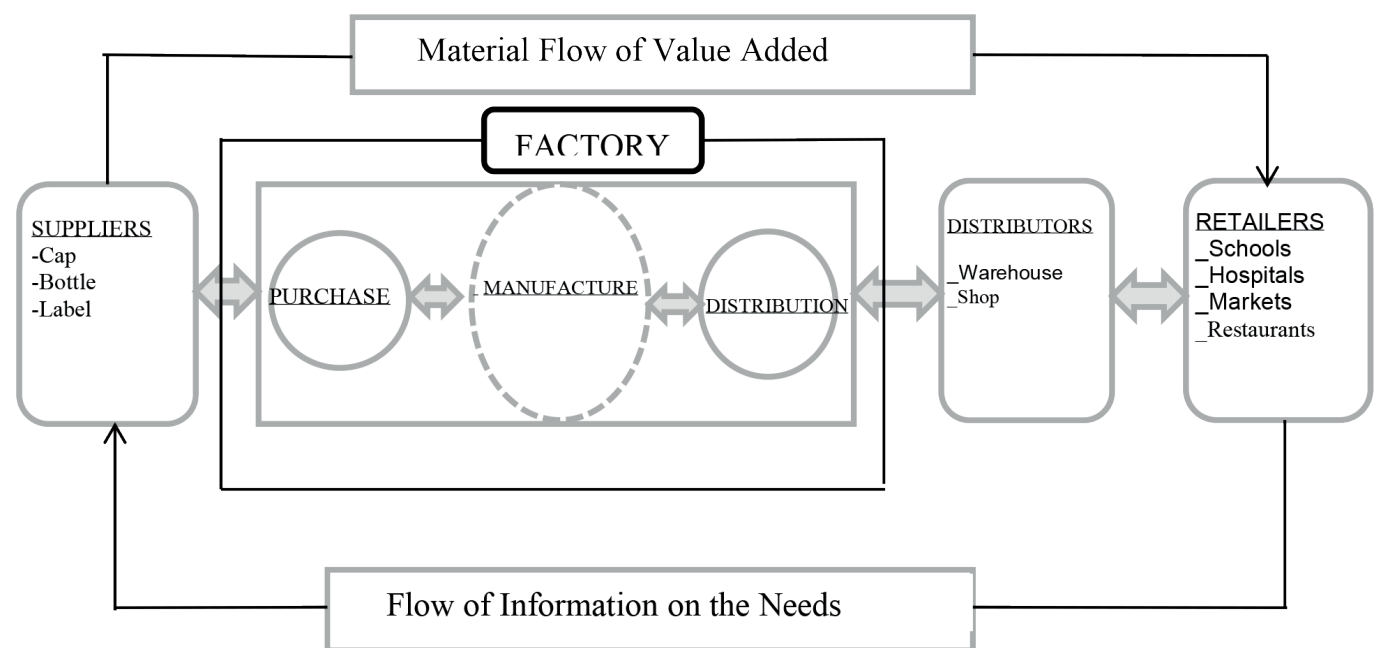

Figure 1. Distribution process of the distributors

company delivers the manufactured products to the distributors. The distributors stock the products in their warehouses and shops. Afterwards, they distribute the products for meeting the needs of the retailers such as supermarkets and restaurants which are responsible for satisfying the needs of the final consumer. For this reason, the chain may be symbolized by a group of companies in various sectors (suppliers, carriers, factories, distributors, retailers, customers) which allow the flow of raw materials, products, money and information in a better way, and thus all the logistics operations improve, and the operating costs decrease (Santos, Marins, Alves \& Moellmann, 2010).

The distribution of the products has two processes, these are physical distribution and the distributors' process. Physical distribution is the delivery of finished products from the factory to the distributors. Physical distribution intends to provide a high level of service in order to establish a smooth flow along the distribution network, and thus, to enable a successful distribution of the products to the right place according to the time set, and at a low cost. The main objective of the distributors is to actualize the procedure in a quality, fast and reliable manner with a lower total cost by satisfying the requirements of the retailers. Distribution covers the operational affairs and controls that allow the transfer of the products from point of manufacture to the points of delivery to the retailers. The main objective of the distribution channel is to deliver the correct products to the right places in a timely manner, and at the lowest cost. As it is mentioned earlier, delivery costs have the highest rate among Operating Costs.

The bottling company (factory) is responsible for assuring the receipt of the products by the distributors. In other words, the factory has to deliver products at the right time, and to the right place with high quality standards. After that point, the company's responsibilities come to an end. For example, if the distributors are not able to sell the products, they cannot send the products back to the company. In addition, the delivery cost belongs to the distributors. When the distributors make a request for the products, the company has to send the products to the distributors within three days. So, it can be said that the distributors are just responsible for distributing the products to retailers, and for the delivery cost (from distributors to retailers). 
Distribution of the distributors is characterized by transportation to various retailers of the required amount of products via pickup trucks conforming to the size of the demand. Some of the distributors operate in large cities, and they have many customers (retailers). Their demands are more than the other customers. As the size of the demand increases, most of the distributors located in big cities have more than one pickup truck to deliver products in a quality manner, and of right size. Other factors considered by the distributors are the customer visits' frequency, delivery amount, sharing the delivery of products, the distance to be handled, time of completing the delivery, and returning the required instruments to office. These factors are very important for the distributors. Because there is no contract between distributors and retailers, so the retailers do not have to sell the distributors' products. They may sell other bottled water companies' products. If the distributors don't have the required features, they may lose the retailers because the bottled water market is subject to competitive market conditions in Turkey. There are many bottled water brands, and the prices of the brands are very close to each other.

\subsection{Factors That Affect The Costs And Revenues Of The Distributors}

Delivery Cost: It covers shipping of the products from the factory to the distributors, and from the distributors to the retailers. The cost depends on some variables such as the distance and quantity. As regards to the distance, some of the distributors have higher delivery costs than the others.

Warehouse and Shop Costs: The costs arise from various elements such as the rents of the shop and warehouse. The distributors have different rental costs due to market conditions, location and size of the warehouse and shop, and some of the distributors have multiple rental costs.

Stock Costs: It covers some costs such as costs for overstocking, keeping stock or keeping less stock, and opportunity cost, cost of capital (which is related to the capital stock, the optimal stock, and the level of investment in stock), cost of the warehouse space (which is related to various costs such as costs for reorganizing stock places in the warehouse, and heating-cooling costs), stock risk costs (deterioration and damage risks), and loading, unloading and returning costs.

Bill Costs: It covers various costs that vary in proportion to goods and services that the business uses such as electric, water, phone, ventilation, heating-cooling, fuel (arising from the distributors' delivery to the retailers) bills.

Staff Wages: All the workers are blue-collar. The distributors pay the workers' wages based on the subsistence wage. The subsistence wage is arranged every year by the government. In addition, it does not cover the wages of the distributor's managers since the managers are actually the owners at all the distributors.

In addition, there are some factors such as regional factors and environmental factors which affect distributors negatively in reaching their goals. These negative factors have a direct effect on costs. Regional and environmental factors cover the location of the distributors. The location of the distributors has a significant effect on rental costs and 
delivery costs. Moreover, all the distributors have at least a warehouse and a shop. As mentioned above, some of the distributors are located in big cities such as Diyarbakir, Batman, Gaziantep, Şanlıurfa and Mardin, while others are located in small cities and towns. It is known that rents in big cities are higher compared to small cities and towns. For this reason, some of the distributors have higher rental costs. The location of the distributors directly affects the delivery costs. If the distributor is located distant from the factory, then it has higher delivery costs than a distributor which is closer to the factory.

The distributors arrange the price of the products. There is no constant price of the products. It plays a significant role in terms of the distributors' revenue (they trade cash or checks with retailers). The distributors obtain revenue in two different ways. The first one is making money from the sales. Secondly, all the factories want the highest sales rate from their distributors. In order to promote the distributors, the company gives them a part of the profit. According to the annual sales of the distributors, the company gives them a part of the profit each year.

Regional and environmental factors such as purchasing power of consumers, demands of the customers, number of customers, and climate of the region can have indirect effects on the revenue of the distributors. As mentioned earlier, some of the distributors are located in big cities, so they can reach more customers than the other distributors. Moreover, it is known that the big cities' inhabitants have higher purchasing power and demands. However, it is not always an advantage. Sometimes the big cities have a cutthroat competition. In addition, the climate of the city has an indirect effect on sales. If the summer season is long in a city, the inhabitants consume more water. And this explains why distributors in the Diyarbakır, Batman, Gaziantep, Şanlıurfa and Mardin Provinces have the highest sales rate, as they are cities with long summer seasons.

\subsection{Additional Information about the Business Distribution}

The common consensus on costs is that the rent (shop and warehouse costs) and delivery costs have a high rate among the total costs. When the size of the distributor enlarges, its rental cost will also increase. In addition, the same relevance exists between the distance and delivery costs. So, if a distributor's place is close to the factory, it has a cost advantage over the distant distributors. The lowest bank guarantee has to be equal to or more than 10,000 TRY. Moreover, all the distributors have to have at least 1 forklift, 1 pallet truck, 1 pickup truck, 2 staff (without manager), 1 warehouse, and 1 store in order to maintain their business. According to the work load of the distributors, the numbers can increase, but they cannot decrease.

\section{Literature Review}

\subsection{Data Envelopment Analysis (DEA)}

Data envelopment analysis (DEA) emerged from the Ph.D. dissertation research of Edwardo Rhodes prepared at Carnegie Mellon University. He evaluated the Project Follow Through by the supervision of W.W. Cooper, and the project was an educational program applied at U.S. public schools aimed at disadvantaged students such as black or Hispanic students. The 
research covered the comparison of the outputs of a set of school districts that were taking part in the project. Copper \& Rhodes (1978)published their first paper, which introduced DEA, in the European Journal of Operational Research. They used DEA to generalize to the multiple-input/multiple-output case the Farrell's (1957) single-input/single-output technical efficiency measure by forming a relative efficiency score as the ratio of a single virtual output to a single virtual input (Farrell, 1957). As a result of the paper, DEA started to be used as a new instrument of management science for technical-efficiency analysis of decision making units (DMUs) in the public sector (Cooper, W.W. 2000).

There are two scale assumptions that are usually evaluated in DEA which are constant returns to scale (CRS), and variable returns to scale (VRS). They cover both increasing and decreasing returns to scale. The assumption of the CRS is that outputs will vary at the same rate as inputs. On the other hand, VRS assumes that production technology can show decreasing, constant and increasing returns to scale (Seiford \& Thrall 1990)

Two different orientation models, which are input-oriented and output-oriented models, can be used for DEA. Input-oriented model can be utilized for evaluating how efficient the input of a firm is used for obtaining the same output level. Determining the reduction in the variable inputs based on fixed outputs and based on a desired output level is possible. In contrast, in output-oriented DEA, the efficient operation of linear programming enables the determination of a firm's potential output that gives its inputs. As Fare had referred for output-oriented models as that "...very much in the spirit of neo-classical production functions defined as the maximum achievable output given input quantities" (Fare, Grosskopf, \& Lovell, 1993).

As reported by Cooper, Seiford and Tone (2007), DEA has also been utilized to provide a new comprehension regarding activities (and entities) for which other methods were used for their assessment. For example, the use of DEA for analyzing the benchmarking applications has identified many sources of inefficiency in some firms with high profitability; and this has provided a means for identifying better benchmarks in many applied studies. Because of these facilities, DEA studies of different organization forms' efficiency have demonstrated that previous research was insufficient in appraising the potentials of such organizations (Cooper, Seiford and Tone 2007).

According to Cooper, Seiford and Zhu (2011), data envelopment analysis (DEA) is a data oriented approach for assessing the performance of a set of decision making units (DMUs). It transforms multiple inputs into multiple outputs. The explanation of a DMU is generic and flexible. We have seen many applications in which DEA was being used to assess the performances of many different kinds of entities engaged in different activities in different contexts in different countries. In addition, DEA applications of these kinds used different forms of DMUs for evaluating the performance of entities, like universities, regions, hospitals, establishments etc. (Cooper, Seiford and Zhu, 2011).

\subsection{Data Envelopment Analysis (DEA) Applications}

Ross \& Droge (2002) utilized 102 distribution centers in order to evaluate distribution centers' performance by the use of the data envelopment model. The aim of the research 
was an integrated benchmarking framework demonstrated in the context of a large supply chain system. The research evaluated distribution centers in a large context, and measured and explained the distribution centers consistently showing best performance by the use of facet analysis, and revealed the performance trends by the use of window analysis on 4 years' data. They used size of workforce, experience, man-hours required (or dollar cost), vehicles (fleet size or capacity), equipment (size or capacity), capital (net present value), and information (demand requirements, machine availability) as the inputs. The inputs represent the major components of a typical distribution center's distribution plan, and the aims of the distribution plan regarding efficient uses of direct labor and distribution vehicles. Also, they utilized the sales volume of four different products as the outputs. They used variable returns to scale DEA model. Their approach developed a new possible direction for appraising distribution center (Ross \& Droge, 2002).

Bigne and Blesa (2003) examined the relation among the market orientation behaviors of manufacturers, and the distributors' trust in the relationship, and their satisfaction. In addition, they studied how the distributors' trust affects their satisfaction. They analyzed three models in which the relation between trust and satisfaction were correlated. They used the Spanish ceramic industry for the application. The results illustrate that trust develops the satisfaction of distributors regarding the relation (Bigne and Blesa, 2003).

Chen (2005) analyzed two models which were joint stock replenishment and temporal shipment consolidation decisions for business distribution, and compared their relative cost effectiveness. According to the shipment release schemes, time based or quantity based models were different from each other. Stock replenishment was creating a lump sum cost to seller. (From suppliers, or shipment to customers). The time-based scheme should had been more efficient, as every cost is time-based, but the quantitative examples demonstrated that the quantity-based scheme always performs at least as well as the time-based scheme. A possible identification would be that the time-based scheme is creating higher waiting costs regarding customers. The results showed that the quantity-based scheme can excel the time-based one while the opposite never occurs (Chen Wang \& Xu, 2005).

Balteiro and Herruzo (2006) analyzed the relation between productive efficiency and innovation activity in Spain's wood-based industry. They used two different methodologies which were a non-parametric technique (data envelopment analysis, DEA), and a logistic regression model. Several inputs and outputs associated with economic and financial data wereused in a non-parametric technique. The logistic regression model was used in order to explore the relation between the property of efficiency, and indicators of innovation activity. The results showed that there was no significant relation between the firm's efficiency and innovation activities (Balteiro, Herruzo, Martinez and Pachón, 2006).

Souza, Macedo and Sales (2010) used data envelopment analysis (DEA) in order to evaluate the relative performance of the 100 supermarket companies being the smallest ones in the list of the 300 largest ones. The results demonstrated that single store companies had performance issues due to economies of scale, while chain stores had issues due to poor technical efficiency. According to the results, the ten largest supermarket companies had better performances than the others (De Souza, April-June 2010). 


\section{Methodology}

The objectives of the DEA are to measure the relative efficiency of the homogeneous decision-making units (DMUs). The efficiency is usually expressed in a ratio form. In the DEA, many inputs' and many outputs' efficiency scores are defined as follows:

Efficiency: Weighted Total Output / Weighted Total Input

DEA is a combination of the many variables, and the relationship of the variables evaluated. It also uses mathematical programming to assess a combination of a large number of inputs and outputs. If we compare DEA with the other approaches, DEA is easier for the user. Furthermore, there are two efficiency orientation models: input and output orientation models. The aim of the input orientation is to minimize inputs for specified output. The purpose of the output orientation is to maximize output for given inputs. In the DEA, the returns to scale are related to how the productivity of an efficient producer changes with the scale size. If inputs increase by a rate, then outputs will increase by that rate. If inputs increase by a greater rate, then outputs will increase by a greater rate, and it increases returns scale. If inputs increase by a rate, then outputs will increase by a lesser rate, and it decreases returns scale. If the rate of increase of the inputs and outputs are the same, then it is constant returns to scale (in the conceptual model part DEA is explained extensively).

\subsection{Conceptual Model of the Research}

\section{Measurement of Efficiency}

Technical efficiency is related to the production of outputs as a result of given inputs. Production plans of the technical efficiency can be applied in two ways. First, if there is no chance to produce more outputs using the same inputs. Secondly, technical efficiency can be applied to produce same outputs by using less inputs. The DMUs (measured technical efficiency) are derived from the frontier. "The measurement of some distance between the observed inputs - outputs combination for a specific DMU and the frontier". Afterwards, the scale efficiency analyzes the shape of the frontier (Favero and Papi, 1995). For these reasons, in this application, technological, scale, pure and efficiency change of the 51 distributors were analyzed by a non-parametric method known as data envelopment analysis (DEA).

Return to scale is related to the way the productivity of an efficient producer changes according to scale size. Also, it is known that it is a feature of the frontier that describes how productivity changes alternatively by scale. It is clear that all the distributors have different cost profiles, and some of them are larger than the others. Also, some of them are distributors at mega cities, and the others at small cities or towns. Therefore, it could be said that the VRS model would be more appropriate for the analysis due to the reasons which proved that VRS is more preferable than CRS.

In addition, the research needs to be controlled in terms of whether there is adequate observation or not before the analysis chapter. There are two general rules of thumb to know the minimum amount of required observation. The below assumptions prove that 
we can accurately assume the VRS-output orientation model for the research analysis. Banker (1989) had suggested a rough rule of thumb (Emrouznejad, 2012).

$($ In the research $) \ldots$ OBSERVATIONS $=51$, INPUTS $=1$ and OUTPUTS $=4$.

1Observations $>3 *($ INPUTS + OUTPUTS $) 151>=3^{*}(1+4)=51>=15$

2Observations $>$ INPUTS $*$ OUTPUT $251>1 * 4=51>4$

\section{The Orientation Model}

At this point, the type of the orientation model has to be arranged. It means that the objectives of the model, which are input or output orientation, should be organized. Walden and Kirkley had stated that an input-oriented technical efficiency model evaluates the vector of inputs used in any output bundle's production, and measures whether a firm is making use of the minimum inputs necessary to produce a specific bundle of outputs. Efficiency is measured by the maximum decrease in inputs which will still allow a specific bundle of outputs to be produced. The output-oriented model demonstrates how much each DMU should increase the output production when the inputs are kept constant (Walden \& Kirkley, 2000).

In the application, if the input variables are considered, it can be seen how highly they are fixed, and how difficult it is to decrease them. Number of the staff can be decreased by the discharge of employees. However, the idea can give the result that the distributors might have to pay extra cost to employees (termination compensation). The distributors cannot reduce the distance easily, because it will deeply change the capital and operating costs. It would be required for the owners of the distributors to rebuild the establishment. So, there is no way to change the distance input. Additionally, size represents the usage of space (warehouse and store). If distributors want to change their warehouse or store, the may pay contract penalties. The distributors cannot change the size variable, and they cannot either change the operational cost, because the operational costs such as utility costs, rent costs and delivering costs are out of the distributors' control, so it would be hard to reduce it as a company. Capital indicates the bank guarantee, and machine and equipment costs. If the capital is changed, selling second hand equipment would be required. This would not be sensible, because the distributors would lose money. In consequence, the input variables are out of the distributors' control. The distributors cannot decrease the input variables. As explained, the input variables are kept constant, then the DMUs analysis is made as output orientation; and the output orientation model shows how much each DMU should increase output production. In other words, in order to maximize the sales, the DEA output orientation model is assigned.

Table 1. Basic DEA model

$\max h_{0}(u, v): \frac{\sum_{r} u_{r} y_{r o}}{\sum_{i} v_{i} x_{i o}}$

subject to: $\frac{\sum_{r} u_{r} y_{r j}}{\sum_{i} v_{i} x_{i j}} \leq 1 j=1,2, \ldots, n$

$u_{i}, v_{j} \geq 0 \quad$ for all $i$ and $r$ $\min h_{0}(v, u): \frac{\sum_{i} v_{i} x_{i o}}{\sum_{r} u_{r} y_{r o}}$

subject to: $\frac{\sum_{i} v_{i} x_{i j}}{\sum_{i} u_{r} y_{r j}} \geq 1 j=1,2, \ldots, n$

$\boldsymbol{u}_{i}, \boldsymbol{v}_{j} \geq \epsilon>0 \quad$ for all $i$ and $r$ 
We suppose that there are n DMUs to be assessed. Each DMU, in order to Each DMU consumes varying amounts of $\mathrm{m}$ different inputs to produce $\mathrm{s}$ different outputs, consumes varying amounts of $m$ different inputs. Especially, DMU $\mathrm{J}_{\mathrm{J}}$ consumes $\mathrm{x}_{\mathrm{ij}}$ amount of input $\mathrm{I}$, and produces $\mathrm{y}_{\mathrm{rj}}$ amount of output $\mathrm{r}$. We assume that $\mathrm{x}_{\mathrm{ij}} \geq 0$, and that at least one positive input and one positive output value are being obtained by each DMU. CCR construction can be interpreted as the decrease of the multiple-output / multiple-input case (for each DMU) to a single "virtual"-output and "virtual"-input. For a particular DMU, the ratio of this single virtual-output to single virtual-input gives a measure of efficiency that is a function of the multipliers. In mathematical programming, this ratio, which is required to be maximized, forms the objective function for the particular DMU under evaluation, and it should be noted that the variables $\mathrm{u}_{\mathrm{r}}, \mathrm{s}$ and the vis and the $\mathrm{y}_{\mathrm{ros}}$ and $\mathrm{x}_{\text {ios }}$ are respectively the observed output and input values of $\mathrm{DMU}_{\mathrm{o}}$ being evaluated. Of course, without further additional constraints, the above equation is unbounded (William W. Cooper, 2005).

\section{The Inputs and Outputs}

Sales: it represents, in terms of the quantity, how many products each distributor sold to the retailers. There is not another way to earn money for the distributors. Selling other products or providing other services is forbidden. All the distributors want to maximize their sales number in order to make money. Because of these reasons, it is obvious that the sales variable is a potential output.

Staff: The data index part defines the amount of labor used in a store and warehouse of the distributors. All the distributors have different workloads, so the number of the staff is different for most of the distributors. It can be said that the higher number of the staff shows that more men are needed to perform the operations required by the distributors. It should be minimized because it is a potential input.

Distance: it shows the distance between the factory and the distributors' final location. If a distributor has a higher distance number, it means that the distributor has to pay a higher delivery cost. It is obvious what a high distance number means for the distributors cost. So, it is an input for the distributor.

Size: it indicates that this variable 'size' facilitates the calculation of the usage of space and its relation to the process of distribution. It is known that large size usage will increase the rent costs. The distributors demand is lower rent costs. So, it is an input.

Capex: it is the monetary value of the bank warranty (license) and machine and equipment (e.g. forklifts, pallet trucks and truck) costs. It is an investment cost of the distributors. The objective of the distributors is to minimize the investment, so it is clear that the variable is a potential input.

\section{Data Collecting Procedures}

The data were obtained directly from the factory; they have a yearly database about all the distributors. The factory sent all the information about the distributors by email. There were some problematic issues with the data. They were complex and huge. The company has many domestic and overseas distributors. To utilize the data for the research, the 
first step was determining the distributors which are domestic distributors. The number of the domestic distributors is more than the overseas distributors. Then, the years were arranged. It is better to use the last two years' data to make the best estimation about the distributors. Then the data were cleaned on excel for a reasonable use in the analysis. The last step was about what the distributors are doing, what is the most important factor on revenue and cost, what is the most important factor of their business, etc. Thanks to the questions, the background information, the data and business distribution were identified. The questions were asked to the distributors directly on the phone and by email. Finally, the data collecting part had three steps, first of all, the data were fixed. Secondly, the data were cleaned. The last step was to clearly understand the business distribution. It is clear that the primary data were used in the research.

\section{Analyses and Results}

\subsection{Basic Statistical Analyses}

The summary (descriptive) statistics illustrate that there is a large dispersal in the values of variables between different activities. In other words, descriptive statistics explains how the variables spread between maximum and minimum values. Also, there is a significant gap between the maximum value and the minimum value of the variables. The minimum values are markedly less than the maximum values. In addition, it is known that if the observation values are close to the mean, the standard deviation value is becoming low and close to the mean without the Capex variable. The table shows that the mean values and standard deviation values are close to each other. So, the standard deviation values are slightly less than the mean values. It means that the observation value of the variables is concentrated around the average.

Table 2. Descriptive Statistics (2012)

\begin{tabular}{|l|c|c|c|c|c|}
\hline Variable & Obs & Mean & Std. Dev. & Min & Max \\
\hline SALES & 51 & 132117.6 & 101678.2 & 30000 & 480000 \\
\hline SIZE & 51 & 154.2353 & 46.57492 & 100 & 250 \\
\hline STAFF & 51 & 3.156863 & 1.405312 & 2 & 8 \\
\hline DISTANCE & 51 & 274.8627 & 150.202 & 10 & 592 \\
\hline CAPEX & 51 & 145627.5 & 44966.19 & 114000 & 265000 \\
\hline
\end{tabular}

By looking at box plots (they are shown in the Appendix part), box plot 1 illustrates that the median of the Sales and Capex are about 120.000 and 114.000 respectively. In terms of the sales, the distributors 10, 28, 11, and 9, which are the Nusaybin, Kiziltepe, Mardin and Gaziantep distributors, have the highest sales quantities. For the Capital Expenditures, the distributors 9, 28 and 1, which are the Mardin, Gaziantep and Diyarbakir distributors, have the highest Capital expenditures. Also, box plots 2 and 3 demonstrate that the median of the distance, size, and staff are 262, 140 and 3 respectively. The DMU 28 and 1 have 8 staff which is the highest number in all the distributors. (All the reasons are discussed in the Discussion Chapter.)

The pairwise correlation Table 3 shows the relationship between the five variables, which are the sales, staff, distance, size, and capex. It is known that the objective of pairwise 


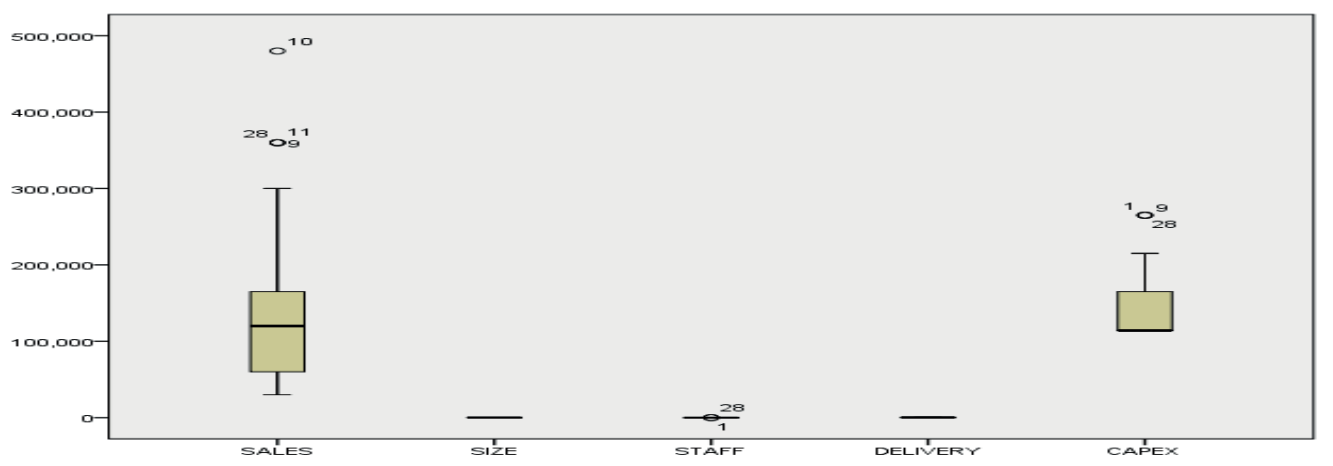

Box plot 1. All The Variables

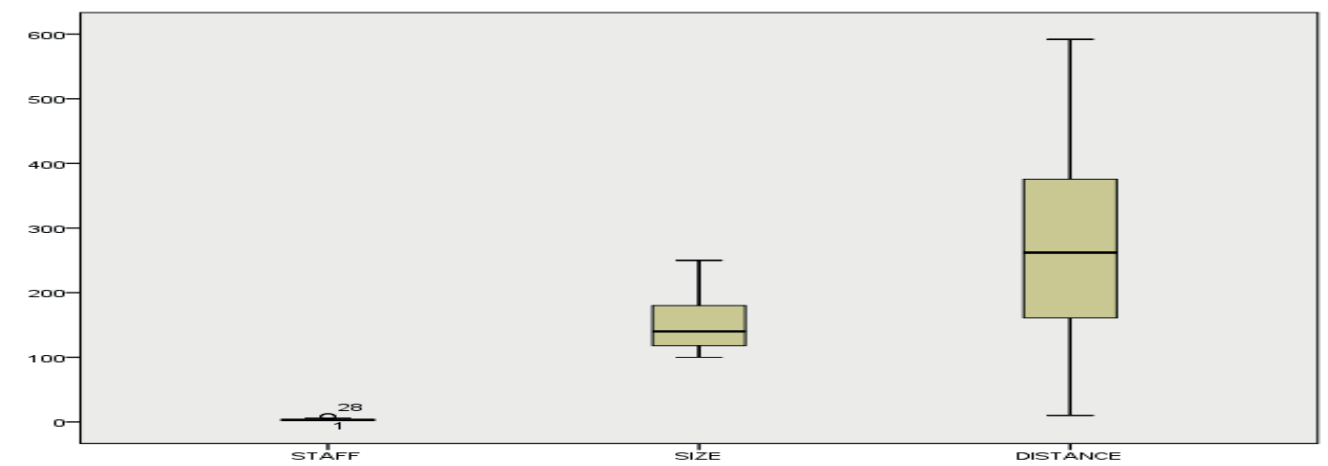

Box plot 2. Delivery Size And Staff Variables

correlation analysis is to assess the closeness of the linear relationship among defined variables. The most important point in a correlation analysis is that we desire a low correlation among inputs variables, while we want a high correlation of input variables with output variables.

Table 3. Pairwise Correlation

\begin{tabular}{|l|c|c|c|c|c|}
\hline & SALES & SIZE & STAFF & DISTANCE & CAPEX \\
\hline SALES & 1 & & & & \\
\hline SIZE & 0.9194 & 1 & & & \\
\hline STAFF & 0.8170 & 0.8061 & 1 & & \\
\hline DISTANCE & -0.3018 & -0.2961 & -0.2276 & 1 & 1 \\
\hline CAPEX & 0.8642 & 0.8749 & 0.7817 & -0.1614 & \\
\hline
\end{tabular}

The distributors determined the number of the staff, size of the warehouse and store, as the sales quantity. Also, the distributors' capex value is in direct proportion to the sales quantity. The reasons explained why most of the inputs and outputs are significantly and positive correlated with each other (without distance variable). In addition to that, before the analysis chapter, it was predicted that most of the variables obviously have a high relation with each other. However, the distance variable seems to be problematic. It has not correlated with other variables. It is obvious that the distance variable is negligible. Because the distance has a negative and low correlation with all the variables. So, the distance variable is excluded from the main model. 


\subsection{Data Envelopment Analysis (DEA)}

Two years of data of the distributors were used in the DEA analysis. First of all, the main model which is the VRS output orientation model was run in order to find the least and the highest efficient distributors. Secondly, the least efficient distributor's peers were investigated and their lambda values were commented on as well. Thirdly, the CRS output orientation model was run to search for the least and the highest efficient distributors on the CRS and MPSS as well. Fourthly, the allocative efficiency of the distributors under cost efficiency was studied. Lastly, the productivity change (Malmquist Index) of the least efficient distributors (VRS and CRS) and productivity change of the all the distributors was investigated.

\section{Variable Returns to Scale (VRS)}

The Vrs-Output oriented model was run in order to investigate the least efficient distributor. As is mentioned before, the inputs are not under the distributors' control and the distributors desire is to maximize their sales quantity which is an output variable in this research. Besides, 13 distributors are $100 \%$ efficient under the VRS. They are the Silvan, Mardin, Nusaybin, Midyat, Siirt, Sirnak, Cizre, Kars, Siverek, Akcakale, Sahinbeyi, Elbistan and Kilis distributors respectively. On the other hand, the Hani distributor is the least efficient distributor within the 51 distributors. (All the distributors efficient results over the two years are shown in the appendix part). It is $33.33 \%$ efficient. In other words, it is $66.66 \%$ inefficient. To comment on the distributor, it is better to search for the actual value, gain value, target value and slack value of the distributor.

Some formulations about Table 4:

Achieved $=($ Actual Value $/$ Target $) * 100$

Sales Achieved Value $=(30000 / 90000) * 100=33.3$

$<$ for output variables $>$ Target $=$ Actual value $*(1+$ GAIN/100 $)$

$90000=30000 *(1+200 / 100)$

$<$ For input variables $>$ Target Value $=$ Actual Value - Slack Value

$114=114-0$ (Size Target Value)

Table 4. Target and slack values for Hani distributor, output orientation

\begin{tabular}{|l|c|c|c|c|c|c|}
\hline Variables & Type & Actual Value & Target & Gain (\%) & Slack & Achieved (\%) \\
\hline SALES & OUTPUT & 30000 & 90000 & 200 & 0 & 33.33 \\
\hline STAFF & INPUT & 2 & 2 & 0 & 0 & 100 \\
\hline SIZE & INPUT & 120 & 120 & 0 & 0 & 100 \\
\hline CAPEX & INPUT & 114000 & 114000 & 0 & 0 & 100 \\
\hline
\end{tabular}

The target values demonstrate the input and output levels that the Hani distributor should use to achieve Pareto efficiency. Besides, it can be said that the increase value for sales is $200 \%$ and it does not have any slack value. The sales can increase to 90000 . Also, the 
model is an output orientated model, the output of which is sales, and should be able to increase at least by:

$100-\operatorname{Eff}(\%)=100-33.33=66.66 \%$

The minimum increase that outputs should achieve to make the unit $100 \%$ efficient is:

$(100-$ Eff $\%) /$ Eff $=100-33.33 / 33.33=\% 200$

From the information, it is obvious that sales should increase by $200 \%$ to become Pareto efficient. In addition, the variable does not have any slack value. If the variable has slack value, the variable can increase by the slack value. The situation is not valid inputs and output variables. Therefore, the variables do not have any slack value in this circumstance.

\section{Peers of the Least Efficient Distributor}

It is known that the Hani distributor is the least efficient within all the distributors. So, the Hani distributor could develop its efficiency by adopting the practices used by its more efficient peers. The efficient peers are the 100\% efficient DMUs with the most similar input mix in an output-oriented model (or most similar output mix in an input oriented one) to the assessed DMUs. It means that they are benchmarks. From the data, it is clear that the Sahinbeyi distributor is an efficient peer with the Hani distributor (The values are represented in Table 6).

Table 5 shows that the Sahinbeyi distributors used the same inputs number but their efficiency is $200 \%$ more than the Hani distributor. In other words, the peers value represents that the Hani distributor can increase sales $200 \%$ with exactly the same inputs. It is an attainable target. The lambda values are the raw weights assigned to the peer unit when solving the DEA model. These $\lambda$ values are the weights that relate to each efficient peer variable value to investigate the ideal benchmark for the Hani distributors. For instance, it is calculated as below (Vrs -Output Size input variable):

Sizetarget, Hani $=\lambda$ Sahinbeyi, IN $*$ SIZESahinbeyi

Table 5. Hani distributor's efficient peers input and output values

\begin{tabular}{|l|c|}
\hline Variables & Sahinbeyi \\
\hline SALES (output) & 90000 \\
\hline STAFF (input) & 2 \\
\hline SIZE (input) & 120 \\
\hline CAPEX (input) & 114000 \\
\hline
\end{tabular}

Table 6. Lambda values for Hani efficient Peers (input and output orientation)

\begin{tabular}{|l|c|}
\hline Lamda & Sahinbeyi \\
\hline$\lambda$ (output) & 1 \\
\hline$\lambda$ (input) & 1 \\
\hline
\end{tabular}




\section{Returns to Scale (CRS-Output)}

Under the CRS-output oriented model, the Mardin and Nusaybin distributors have the highest efficient value, however, the Araban Distributor has the least efficient within 51 distributors. The efficiency value of Araban is 15 . In other words, it is $85 \%$ inefficient. It operates under increasing returns to scale and its scale efficiency is:

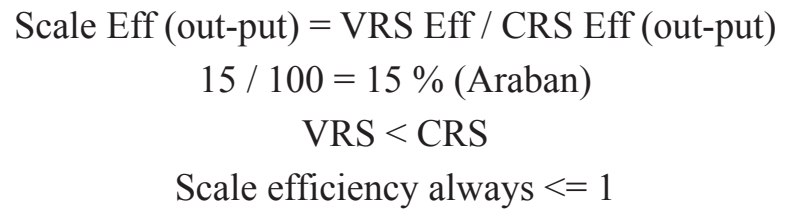

Variable Returns to Scale (VRS) hold when the CRS do not hold for all scales of operation. In addition, the explanation of the MPSS is that MPSS corresponds to the maximum productivity attainable in the single input -single output case, it corresponds to the maximum output to input ratio.

\section{Allocative Efficiency}

Allocative efficiency contends with minimizing the cost of production with a proper combination of inputs to a specified level of outputs and a set of input costs. To produce minimum outputs, we need an optimal input combination. Because of this reason, all the distributors have to use the correct ratio of the combined inputs and be technically efficient at low prices in order to produce output with a minimum cost. Thanks to the results, the distributors will have profit maximization. To sum up, allocative efficiency assesses the DMU capability to minimize cost so that output is produced at a minimal cost (Allocative Efficiency $=$ Cost Efficiency * Efficiency).

In the allocative analysis, the new model, which is allocative efficiency, is run with VRSoutput oriented model and for the allocative type cost efficient chosen. Then, the inputs values are written for all the distributors. The six distributors which are Nusaybin, Cizre, Kars, Siverek, Sahinbeyi, and Elbistan are $100 \%$ efficient based on the cost allocative efficiency analysis (The values are calculated, and all the distributors cost and allocative efficiencies are demonstrated in the Appendix chapter).

Staff: 1 Staff salary is 886 TL the first year, and 978 the second year for all the distributors. As is mentioned before the distributors pay subsistence wages for all the staff.

Size (rent / m2): (Each of the distributors' rent cost / Each of the distributors' size). We obtained one square meter payment of the distributors.

Capex: the capex variable indicated the distributors' capital expenditure differently. So, we wrote just one for all the distributors.

\section{Productivity Change (Malmquist Index)}

The Malmquist analysis measures the productivity changes for distributors from 2012 to 2013. Besides, the Malmquist index measures productivity change top-down. Also, if the pure efficiency, scale efficiency change and technological change are calculated, 
the productivity change (\%) over the time of the distributors can be obtained for each distributor. In this research, data of the distributors were used between 2012 and 2013, and the Malmquist analysis output of the 2012 and 2013 data (VRS-output oriented model) gave the Malmquist Index (MI), the efficiency change (EC) and the technological change (TC) for all distributors. First of all, the CRS-output oriented model and the FGNZ Index (CRS) were chosen, then the model was run to obtain the results. In addition, the Malmquist Index value of Hani is $-1.13 \%$. It means that the distributor's productivity decreased in the second year (TC $(2.96 \%)<\mathrm{EC}(-4.08))$. The productivity of the distributor was stable in the second year. The Araban distributor's Malmquist Index is $2.96 \%$ ( $\mathrm{EC}(2.96)>\mathrm{TC}(0))$. In other words, the distributor's productivity increased in the second year $(\mathrm{MI}=\mathrm{TC} * \mathrm{EC})$.

\section{Pure Efficiency Change}

The Hani and Araban distributors' pure efficiency values are $1.10 \%$ and $109.87 \%$ respectively. Both distributors became much more close to the VRS frontier in the second year. Pure efficiency change measures how much the evaluated distributors in the period are closer to (or further away from) the VRS frontier in period $t+1$. So, the distributors are further away from the VRS frontier in the second year (PEC: VRS Y2 / Y1).

\section{Efficiency Change}

Efficiency change demonstrates whether a distributor shifted or not (closer to or further from) the CRS frontier. In other words, it indicates the distributors' changed efficiency. It decomposed from pure efficiency (PEC) and scale efficiency change (SEC). The formulation of the efficiency change is shown below, and all the distributors' efficiency change is demonstrated in the Appendix chapter.

\section{EC $=$ Pure Efficiency change * Scale Efficiency Change}

The Araban distributor is the least efficient within the 51 distributors, under the CRS (all the distributors' results are illustrated in the Appendix chapter). Under the VRS, the efficiency of the Hani distributor decreased by $-4.08 \%$ from the first year to the second year. Also, the Araban distributor is the least efficient distributor under the CRS, the distributor increased efficiency by 2.96 , but the frontier is stable in the frontier (the virtual benchmark of the Suruc distributor has become - $1.01 \%$ less efficient). Regarding the efficiency change, the pure efficiency of the Hani distributor is $1 \%$, and the scale efficiency change of the distributor is $-5.19 \%$. Because of this reason, the efficiency change is $-4.08 \%$, and it has a negative impact on the overall productivity.

\section{Scale Efficiency Change}

Scale efficiency change indicates how much more (or less) scale efficient the evaluated distributors are in period $t+1$. Also, the Araban and Hani Distributors' scale efficiency results are $-106.92 \%$ and $-5.19 \%$ respectively. It is obvious that the scale efficiency of the Araban distributor decreased significantly in the second year, and the Hani distributor decreased in the second year. It means that both distributors moved away from their most productive scale size in the second year. The scale efficiency change is given by the combination of these two components: SEC: Scale Efficiency Y2 / Scale Efficiency Y1. 


\section{Technological Change (Frontier Shift)}

Technological change (frontier shift) measures the same interpretation as before by how much the productivity of the benchmark of the evaluated distributors improved or deteriorated. Furthermore, the Hani and Araban distributors' technological change values are $2.96 \%$ and $0 \%$ respectively. In other words, the productivity of the benchmark of the Araban distributor is stable in the second year, whereas the Hani distributor's assessed benchmark (peers) distributor increased (TC (Frontier Shift): Malmquist index / Efficiency Change)).

\section{General Change in The Productivity for All the Distributors}

Overall, if the productivity change components for all the distributors are taken into account, it can draw some important results about the distributors' performance evolution. From Table 8, it is obvious that most of the evaluated distributors could not manage to improve their productivity during the two years, because the average of the distributors is less than 1. It is known that some of the distributors' productivity increased, and some of them decreased. The productivity of the distributors takes a value between 14.84 and $-14.93(\%)$. However, the average of the technological change increased by $0.85 \%$. It means that the benchmarks of the distributors increased, but the efficiency change decrease is more than the technological change decrease. It also explains why the distributors MI average is negative. Furthermore, the scale efficiency change average of the distributors is negative, which means that the distributors moved away from their most productive scale size. However, the pure efficiency change average of the distributors is 1.53 . The average of the distributors becomes closer to the VRS frontier in the second year.

Table 7. Actual and Most Productive Scale Size for Hani Distributor

\begin{tabular}{|l|c|c|}
\hline Variables & Target Value & MPSS \\
\hline SALES( output ) & 90000 & 200304.88 \\
\hline STAFF( input ) & 2 & 4.45 \\
\hline SIZE( input ) & 120 & 267.07 \\
\hline CAPEX( input ) & 114000 & 253719.51 \\
\hline
\end{tabular}

Table 8. General Change In The Productivity For All The Distributors

\begin{tabular}{|l|c|c|c|c|c|}
\hline & TC(\%) & MI(\%) & EC(\%) & SEC(\%) & PEC (\%) \\
\hline AVG & 0.85 & -0.27 & -1.12 & -2.65 & 1.53 \\
\hline MIN & -13.93 & -14.93 & -18.63 & -106.92 & -15.27 \\
\hline MAX & 9.53 & 14.84 & 14.84 & 15.27 & 109.87 \\
\hline STD DEV & 4.59 & 6.01 & 7.18 & 16.01 & 17.27 \\
\hline
\end{tabular}

\section{Discussion and Conclusion}

It is known that the civil conflict started in Syria in 2011, and it is still continuing. Besides, the Republic of Turkey has 13 border gates with Syria. They are in Mardin (2), Sanliurfa (3), Gaziantep (2), Hatay (4), Kilis (1), Sirnak (1). After the civil war started, 
Turkey accepted all the refugees from Syria. They are more than 4 million. The Turkish government built tent cities in Mardin, Sanliurfa and Gaziantep. So, the extraordinary situation affected the research results directly, since water is a kind of indispensable product. All people have to drink water every day. Furthermore, in these tent cities, refugees are drinking bottled water. This circumstance affects the results of the Mardin distributor and Mardin town's distributors (Nusaybin, Kiziltepe and Midyat), Gaziantep distributors and Gaziantep town's distributors (Sahinbeyi, Sehitkamil), Sirnak distributor and Sirnak town's distributor (Cizre) sales directly. According to the box plot (appendix box plot 1) results, the Mardin distributor and its town distributors which are Nusaybin and Kiziltepe have the highest sales quantity within all the distributors. Also, the Gaziantep distributor is another distributor that has the highest sales value. Besides, Gaziantep is a big city. It is the most developed city, and it is the most qualified industrial city of Turkey's south east region. It has a population of about two million people. So, the situation of the Gaziantep is negotiable. We cannot say that the sales number of Gaziantep is just due to the refugees from Syria. Also, it is important to figure out that Mardin city and its towns water quality is too low. There are two dams in Mardin. The city 's water is supplied from these dams. Their dam water base level is low. The dams were built in 1985, so they are old dams. Thus, the tap water quality is low. Because of that, Mardin city and its town citizens cannot drink tap water. It can be another factor to explain why Mardin and its town have a high sales quantity number.

In terms of the Capex and Staff variables, the Diyarbakir, Gaziantep and Mardin distributors have the greatest value because these distributors are located in big cities. They have to have more machines (trucks and other machines) and equipment to reach retailers just in time. Also, we know that the rent costs of the big cities are more than in small cities and the towns. So, they have to pay for more rent costs than the other distributors. The situation supports both assumptions. Nusaybin, Kiziltepe, Midyat are towns of Mardin city, and the population of Mardin is greater than theirs, but they have more sales quantity than Mardin. It can be concluded that the town of Mardin cities distributors is affected by the refugees from Syria. As the analysis results show, it is clear that the Mardin, Diyarbakir, Gaziantep, and Sanliurfa distributors and their town distributors have the highest sales quantity numbers. Also, it can be explained by the weather conditions of the cities. The cities are located in the south east of Turkey. The region is the warmest region of Turkey. The average temperature of the region is more than $35 \mathrm{C}$ in spring and summer time. Also, the yearly average temperature of the region is more than $25 \mathrm{C}$. It is known that there is positive correlation between water consumption and temperature. It means that if thetemperature rises, the water demands will increase. According to the weather average of the region, these cities are very hot. It can be another important reason why the distributors sales quantity is higher than the other distributors.

In the analysis the DEA, results of the distributors are obtained. As a result of the DEA analysis, all the big cities could not be $100 \%$ efficient without Mardin city. It is interesting that most of the big cities' town distributors are $100 \%$ efficient such as Nusaybin, Midyat, Sahinbeyli, etc. The situation is valid for the two years' efficiency of the distributors. As well, the same situation continues in allocative efficiency results. The town distributors are 
again $100 \%$ efficient as Nusaybin, Sahinbeyli distributors. Rent costs of the distributors can be the main results, because the distributors have to store and warehouse, and the cost of the rent is more in big cities than in the small cities and towns. However, all the distributors pay subsistence wages to their staff, but the big city's distributors have to have more staff. So, these reasons explain why the town distributors are more efficient than the city distributors in allocative efficiency.

To sum up, in this research, we used real data of a water bottling factory's 51 distributors over two years. The distributors' efficiency and productivities analyses were obtained via Data Envelopment Analysis (DEA) results with four parameters: Sales, Staff, Size and Capex (the delivery variable is excluded from the model in the correlation analysis). The productivity of the distributors is also analyzed over the two years in these results. In addition to that, it is important to discuss the result of the analysis after the analyses and results since, before the analysis, we got different results from the assumptions (big cities distributors' efficiencies are better than the small cities and town distributors). This is because of the global conflict (war in Syria), Turkish government policies (accepting the war refugees) and the other reasons (natural and environmental). Furthermore, as the productivity analyses of the DEA approaches, the big cities distributor's productivities are less than the small cities and towns distributors. Because of these reasons, the small cities and towns distributor's efficiency and productivities are better than the big cities distributors (the reasons are explained in depth in the discussion).

\subsection{Recommendations}

In the DEA analysis results, some of the distributors' efficiencies are low, for instance, the Hani, Araban, Suruc, Hakkari, and Adiyaman distributors are the least efficient distributors (the Araban distributor is $100 \%$ efficient in the second year). The efficiency of the distributors is less than $\% 50$. The first step should be to check the distributors' benchmarks (peers), because the manager can see their capacity. In other words, the manager can figure out how much we can increase our sales with specified inputs. The Hani and Araban distributors analysis is done in the analysis chapter (Hani was the least efficient distributor over the two years under the VRS-output oriented model, and the Araban distributor is the least efficient distributor under the CRS-output oriented model over the two years).

Another important point is the productivity of the distributors. In the results, the productivity of the Cizre distributors decreased significantly in the second year. Cizre is a town of Sirnak city. Besides, the Sirnak distributor's efficiency decreased by $-5 \%$. It clear that the Cizre distributor's sales quantity decreased in the second year (by 2000), and the number of the Capex increased. So, the investment decreased the efficiency of the Distributor.

According to the total number of the parameters, the number of the sales and capex change in the second year. There is small increase in the number of the sales variable (about 6000), however, the capex variable increased significantly. Also, the staff wages increased in the second year. These reasons explain also why most of the distributors' efficiency 
decreased in the second year. It is obvious that the number of the inputs increased more than the number of the outputs. Because of these reasons, we can suggest to the manager of the distributors that they should be careful about their internal resources. These kinds of spending decrease their efficiency. They should not increase their inputs more than their outputs.

\subsection{Research Limitations (Constraints)}

It is better to start with the parameters, because some of the variables are dropped from the model before the main analysis (DEA). First, the distance (delivery) variables are excluded from the model in the correlation analysis. It measures the distance between the factory and the distributors' final location (warehouse or store). But the parameter can develop, and it may be suitable to analyze for other researchers. For example, the distance from a distributor to its retailers. Tthe rent cost and transportation costs are the main expenditure of the distributors. It is better to have more parameters in the analysis. In addition to that, the Capex variable measured the second hand price of their machines and equipment. It is not easy to find the real value of the distributors' machines and equipment because some of the distributors bought them many years ago, and some of them bought second hand. It is a constraint (limitation) of the research. Another limitation of the research is the market structure of the distributors, and where they are located. Maybe there is a competitive market in their cities or towns. For example, maybe there are many water bottling factories or companies in the distributor's city or there is not any water bottling company or companies. It is another limitation of the research. So, if we know about these kinds of the constraints, the research can be a more in-depth analysis, and the results can be more reliable.

\subsection{Future Research}

The efficiency of the distributors is evaluated as their sales quantities and the inputs. Also, the research can apply to the sales price of the distributors because there is no fixed price. Besides, the sales price can show the market structure, and the efficiency of the distributors assessed with new parameters. In addition to that, the variables can change as one output and two inputs. The output can be sales quantities or sales price of the distributors. In terms of the inputs, one of them can be the operational expenditures: utility costs, delivery costs, staff costs, etc. Another input can be the capital expenditures: bank warranty to obtain sales license for the factory and machines and equipment. Besides, some also have overseas distributors (Iraq distributors). The model can be more general with a larger number of DMUs.

Peer-review: Externally peer-reviewed.

Conflict of Interest: The author has no conflict of interest to declare.

Grant Support: The author declared that this study has received no financial support.

Hakem Değerlendirmesi: Dış bağımsız.

Çıkar Çatışması: Yazar çıkar çatışması bildirmemiştir.

Finansal Destek: Yazar bu çalışma için finansal destek almadığını beyan etmiştir. 


\section{References}

Bigne, E., \& Blesa, A. (2003). Market orientation, trust and satisfaction in dyadic relationships: a manufacturerretailer analysis. International Journal of Retail \& Distribution Management, 31(11), 574-590.

Chen, F. Y., Wang, T., \& Xu, T. Z. (2005). Integrated inventory replenishment and temporal shipment consolidation: A comparison of quantity-based and time-based models. Annals of Operations Research, 135(1), 197-210.

Cooper, W. W. (2007). Seiford. LM and Tone, K.(2000) Data Envelopment Analysis: A Comprehensive Text with Models, Applications, References and DEA-Solver Software.

Cooper, W. W. vd.(2000), “Data Envelopment Analysis: A Comprehensive Text with Models, Applications, References and DEASolver Software".

Cooper, W. W., Seiford, L. M., \& Zhu, J. (2011). Data envelopment analysis: History, models, and interpretations. In Handbook on data envelopment analysis (pp. 1-39). Springer, Boston, MA.

Cooper, W. W., Seiford, L. M., \& Zhu, J. (2011). Data envelopment analysis: History, models, and interpretations. In Handbook on data envelopment analysis (pp. 1-39). Springer, Boston, MA.

De Souza, M. M. M. \&. F., April-June 2010. 'Performance of Brazilian supermarket companies: a Data Envelopment Analysis approach/Desempenho organizacional setor supermercadista. Faculdade de Economia, Administracao e Contabilidade, 17(2), pp. p151, 17.

Diaz-Balteiro, L., Herruzo, A. C., Martinez, M., \& González-Pachón, J. (2006). An analysis of productive efficiency and innovation activity using DEA: An application to Spain's wood-based industry. Forest Policy and Economics, 8(7), 762-773.

Emrouznejad, A., 2012. www.deazone.com. [Online] Available at: http://deazone.com/en/cooper-framework/ cooperframework-phase4 [Accessed 0603 2018].

Fare, R., Grosskopf, S., \& Lovell, C. (1993). Frontmatter. In Production Frontiers (pp. I-Viii). Cambridge: Cambridge University Press.

Farrell, M., 1957. The Measurement of Productive Efficiency. Journal of the Royal Statistical Society, 3(1), pp. 253-290 .

Favero, C. A., \& Papi, L. (1995). Technical efficiency and scale efficiency in the Italian banking sector: a non-parametric approach. Applied economics, 27(4), 385-395.

Ross, A., \& Droge, C. (2002). An integrated benchmarking approach to distribution center performance using DEA modeling. Journal of Operations Management, 20(1), 19-32.

Dos Santos, R. F., Marins, F. A. S., Alves, J. M., \& Moellmann, A. H. (2010). A real application of the theory of constraints to supply chain management in Brazil. Brazilian Journal of Operations \& Production Management, 7(2), 81-100.

Seiford, L. M., \& Thrall, R. M. (1990). Recent developments in DEA: the mathematical programming approach to frontier analysis. Journal of econometrics, 46(1-2), 7-38.

Walden, J., \& Kirkley, J. E. (2000). Measuring technical efficiency and capacity in fisheries by data envelopment analysis using the General Algebraic Modeling System (GAMS): A workbook. US Department of Commerce, National Oceanic and Atmospheric Administration, National Marine Fisheries Service, Northeast Region, Northeast Fisheries Science Center.

William W. Cooper, L. M. S. a. J. Z., 2005. History, Models and Interpretations. DATA ENVELOPMENT ANALYSIS, XIII(8), p. 1266. 
Ek 1.

\begin{tabular}{|c|c|}
\hline Distributors & Efficiency (VRS-Output) \\
\hline HANI & 33.33 \\
\hline ARABAN & 33.33 \\
\hline SURUC & 37.04 \\
\hline HAKKARI & 38.89 \\
\hline ADIYAMAN & 42.11 \\
\hline ANTAKYA & 45.16 \\
\hline BISMIL & 50 \\
\hline KOZLUK & 50 \\
\hline BULANIK & 50 \\
\hline MERSIN & 52.63 \\
\hline ISKENDERUN & 58.26 \\
\hline MALATYA & 59.32 \\
\hline REYHANLI & 60.54 \\
\hline DIYARBAKIR & 62.5 \\
\hline VAN & 62.57 \\
\hline ELAZIG & 63.08 \\
\hline ADANA & 65.22 \\
\hline AGRI & 66.67 \\
\hline AFSIN & 66.67 \\
\hline BINGOL & 66.67 \\
\hline КАНТА & 66.67 \\
\hline SIVAS & 66.67 \\
\hline BIRECIK & 68.97 \\
\hline ERZURUM & 68.97 \\
\hline BITLIS & 71.43 \\
\hline SEHITKAMIL & 73.31 \\
\hline K.MARAS & 74.43 \\
\hline BATMAN & 74.89 \\
\hline GAZIANTEP & 75 \\
\hline PATNOS & 80 \\
\hline MUS & 80 \\
\hline URFA & 81.81 \\
\hline CERMIK & 82.35 \\
\hline NIZIP & 87.08 \\
\hline KURTALAN & 87.39 \\
\hline HILVAN & 89.04 \\
\hline KIZILTEPE & 89.7 \\
\hline ERGANI & 92.2 \\
\hline SILVAN & 100 \\
\hline MARDIN & 100 \\
\hline NUSAYBIN & 100 \\
\hline MIDYAT & 100 \\
\hline SIIRT & 100 \\
\hline SIRNAK & 100 \\
\hline CIZRE & 100 \\
\hline KARS & 100 \\
\hline SIVEREK & 100 \\
\hline AKCAKALE & 100 \\
\hline SAHINBEYI & 100 \\
\hline ELBISTAN & 100 \\
\hline KILIS & 100 \\
\hline
\end{tabular}




\begin{tabular}{|c|c|}
\hline Distributors & Efficiency ( CRS-Output ) \\
\hline ARABAN & 15 \\
\hline HANI & 17.25 \\
\hline SURUC & 17.25 \\
\hline BISMIL & 17.76 \\
\hline KOZLUK & 17.76 \\
\hline BULANIK & 17.76 \\
\hline HAKKARI & 24.55 \\
\hline AGRI & 34.5 \\
\hline BIRECIK & 34.5 \\
\hline AFSIN & 34.5 \\
\hline BITLIS & 34.5 \\
\hline BINGOL & 34.5 \\
\hline КАНТА & 34.5 \\
\hline ERZURUM & 34.5 \\
\hline SIVAS & 34.5 \\
\hline PATNOS & 34.62 \\
\hline MUS & 34.62 \\
\hline KARS & 35.53 \\
\hline ELBISTAN & 35.53 \\
\hline ADIYAMAN & 36.68 \\
\hline ANTAKYA & 37.09 \\
\hline SEHITKAMIL & 37.17 \\
\hline K.MARAS & 37.17 \\
\hline CERMIK & 38.14 \\
\hline KILIS & 45 \\
\hline MERSIN & 45.85 \\
\hline ISKENDERUN & 46.41 \\
\hline REYHANLI & 46.55 \\
\hline MALATYA & 46.75 \\
\hline VAN & 47.04 \\
\hline ERGANI & 49.56 \\
\hline HILVAN & 49.56 \\
\hline AKCAKALE & 49.56 \\
\hline SIRNAK & 51.75 \\
\hline SAHINBEYI & 51.75 \\
\hline ELAZIG & 55.03 \\
\hline ADANA & 55.18 \\
\hline SILVAN & 58.94 \\
\hline SIVEREK & 59.47 \\
\hline DIYARBAKIR & 62.5 \\
\hline SIIRT & 66.67 \\
\hline NIZIP & 69.52 \\
\hline KURTALAN & 69.61 \\
\hline CIZRE & 70.11 \\
\hline BATMAN & 72.91 \\
\hline GAZIANTEP & 75 \\
\hline URFA & 76.84 \\
\hline KIZILTEPE & 87.43 \\
\hline MIDYAT & 88.89 \\
\hline MARDIN & 100 \\
\hline NUSAYBIN & 100 \\
\hline
\end{tabular}




\begin{tabular}{|c|c|c|}
\hline Distributors & COST Efficiency (VRS-Output) & Allocative Efficiency (VRS-Output) \\
\hline HANI & 99.89 & 299.68 \\
\hline ARABAN & 99.25 & 297.74 \\
\hline SURUC & 99.95 & 269.86 \\
\hline HAKKARI & 69.51 & 178.74 \\
\hline ADIYAMAN & 69.12 & 164.17 \\
\hline ANTAKYA & 69.59 & 154.09 \\
\hline BISMIL & 100 & 200 \\
\hline KOZLUK & 100 & 200 \\
\hline BULANIK & 100 & 200 \\
\hline MERSIN & 69.74 & 132.5 \\
\hline ISKENDERUN & 69.92 & 120.01 \\
\hline MALATYA & 69.75 & 117.58 \\
\hline REYHANLI & 69.99 & 115.62 \\
\hline DIYARBAKIR & 58.65 & 93.84 \\
\hline VAN & 69.98 & 111.85 \\
\hline ELAZIG & 71.12 & 112.76 \\
\hline ADANA & 70.59 & 108.23 \\
\hline AGRI & 99.8 & 149.7 \\
\hline AFSIN & 99.86 & 149.79 \\
\hline BINGOL & 99.86 & 149.79 \\
\hline КАНТА & 99.8 & 149.7 \\
\hline SIVAS & 99.84 & 149.76 \\
\hline BIRECIK & 99.87 & 144.81 \\
\hline ERZURUM & 99.87 & 144.81 \\
\hline BITLIS & 99.92 & 139.88 \\
\hline SEHITKAMIL & 99.12 & 135.21 \\
\hline K.MARAS & 99.18 & 133.26 \\
\hline BATMAN & 72.93 & 97.39 \\
\hline GAZIANTEP & 66.24 & 88.31 \\
\hline PATNOS & 99.92 & 124.9 \\
\hline MUS & 99.92 & 124.9 \\
\hline URFA & 67.32 & 82.29 \\
\hline CERMIK & 99.26 & 120.53 \\
\hline NIZIP & 70.92 & 81.45 \\
\hline KURTALAN & 71.24 & 81.51 \\
\hline HILVAN & 99.63 & 111.89 \\
\hline KIZILTEPE & 81.88 & 91.29 \\
\hline ERGANI & 99.69 & 108.13 \\
\hline SILVAN & 98.6 & 98.6 \\
\hline MARDIN & 66.97 & 66.97 \\
\hline NUSAYBIN & 100 & 100 \\
\hline MIDYAT & 64.22 & 64.22 \\
\hline SIIRT & 70.29 & 70.29 \\
\hline SIRNAK & 99.88 & 99.88 \\
\hline CIZRE & 100 & 100 \\
\hline KARS & 100 & 100 \\
\hline SIVEREK & 100 & 100 \\
\hline AKCAKALE & 99.83 & 99.83 \\
\hline SAHINBEYI & 100 & 100 \\
\hline ELBISTAN & 100 & 100 \\
\hline KILIS & 99.5 & 99.5 \\
\hline
\end{tabular}




\begin{tabular}{|c|c|c|}
\hline Distributors & First Efficiency (VRS-Output) & Second Efficiency (VRS-Output) \\
\hline ADANA & 65.22 & 59.44 \\
\hline ADIYAMAN & 42.11 & 46.04 \\
\hline AFSIN & 66.67 & 67.39 \\
\hline AGRI & 66.67 & 63.46 \\
\hline AKCAKALE & 100 & 100 \\
\hline ANTAKYA & 45.16 & 44.54 \\
\hline ARABAN & 33.33 & 100 \\
\hline BATMAN & 74.89 & 82.26 \\
\hline BINGOL & 66.67 & 64.13 \\
\hline BIRECIK & 68.97 & 67.98 \\
\hline BISMIL & 50 & 48.79 \\
\hline BITLIS & 71.43 & 72.09 \\
\hline BULANIK & 50 & 46.77 \\
\hline CERMIK & 82.35 & 78.39 \\
\hline CIZRE & 100 & 100 \\
\hline DIYARBAKIR & 62.5 & 71.73 \\
\hline ELAZIG & 63.08 & 67.22 \\
\hline ELBISTAN & 100 & 98.39 \\
\hline ERGANI & 92.2 & 79.14 \\
\hline ERZURUM & 68.97 & 66.29 \\
\hline GAZIANTEP & 75 & 87.32 \\
\hline HAKKARI & 38.89 & 37.2 \\
\hline HANI & 33.33 & 33.7 \\
\hline HILVAN & 89.04 & 80.45 \\
\hline ISKENDERUN & 58.26 & 52.29 \\
\hline K.MARAS & 74.43 & 68.28 \\
\hline KAHTA & 66.67 & 63.46 \\
\hline KARS & 100 & 100 \\
\hline KILIS & 100 & 100 \\
\hline KIZILTEPE & 89.7 & 95.85 \\
\hline KOZLUK & 50 & 51.61 \\
\hline KURTALAN & 87.39 & 79.32 \\
\hline MALATYA & 59.32 & 64.91 \\
\hline MARDIN & 100 & 100 \\
\hline MERSIN & 52.63 & 48.83 \\
\hline MIDYAT & 100 & 96.51 \\
\hline MUS & 80 & 79.22 \\
\hline NIZIP & 87.08 & 88.36 \\
\hline NUSAYBIN & 100 & 100 \\
\hline PATNOS & 80 & 76.62 \\
\hline REYHANLI & 60.54 & 58.89 \\
\hline SAHINBEYI & 100 & 100 \\
\hline SEHITKAMIL & 73.31 & 100 \\
\hline SIIRT & 100 & 100 \\
\hline SILVAN & 100 & 95.54 \\
\hline SIRNAK & 100 & 92.59 \\
\hline SIVAS & 66.67 & 61.25 \\
\hline SIVEREK & 100 & 94.84 \\
\hline SURUC & 37.04 & 38.55 \\
\hline URFA & 81.81 & 87.93 \\
\hline VAN & 62.57 & 61.63 \\
\hline
\end{tabular}




\begin{tabular}{|c|c|c|c|c|}
\hline Distributors & PEC & SEC & EC & TC \\
\hline ADANA & 0.91 & 1.03 & 0.94 & 0.96 \\
\hline ADIYAMAN & 1.09 & 1.04 & 1.13 & 0.94 \\
\hline AFSIN & 1.01 & 0.96 & 0.97 & 1.02 \\
\hline AGRI & 0.95 & 1.02 & 0.97 & 1 \\
\hline AKCAKALE & 1 & 1.1 & 1.10 & 0.95 \\
\hline ANTAKYA & 0.99 & 1.04 & 1.03 & 0.96 \\
\hline ARABAN & 3 & 1.02 & 3.06 & 0.34 \\
\hline BATMAN & 1.1 & 1.03 & 1.13 & 0.97 \\
\hline BINGOL & 0.96 & 0.96 & 0.92 & 1.02 \\
\hline BIRECIK & 0.99 & 1.18 & 1.17 & 0.84 \\
\hline BISMIL & 0.98 & 1.44 & 1.41 & 0.72 \\
\hline BITLIS & 1.01 & 1.16 & 1.17 & 0.86 \\
\hline BULANIK & 0.94 & 1.44 & 1.35 & 0.72 \\
\hline CERMIK & 0.95 & 1.2 & 1.14 & 0.87 \\
\hline CIZRE & 1 & 0.89 & 0.89 & 0.97 \\
\hline DIYARBAKIR & 1.15 & 1 & 1.15 & 1 \\
\hline ELAZIG & 1.07 & 1.08 & 1.16 & 0.92 \\
\hline ELBISTAN & 0.98 & 1.02 & 1.00 & 1.01 \\
\hline ERGANI & 0.86 & 1.22 & 1.05 & 0.91 \\
\hline ERZURUM & 0.96 & 1.18 & 1.13 & 0.84 \\
\hline GAZIANTEP & 1.16 & 1 & 1.16 & 1 \\
\hline HAKKARI & 0.96 & 1 & 0.96 & 1.01 \\
\hline HANI & 1.01 & 0.96 & 0.97 & 1.02 \\
\hline HILVAN & 0.9 & 1.21 & 1.09 & 0.89 \\
\hline ISKENDERUN & 0.9 & 1.04 & 0.94 & 1.02 \\
\hline K.MARAS & 0.92 & 1.27 & 1.17 & 0.83 \\
\hline КАНTA & 0.95 & 1.02 & 0.97 & 1 \\
\hline KARS & 1 & 1.03 & 1.03 & 1 \\
\hline KILIS & 1 & 1.01 & 1.01 & 1 \\
\hline KIZILTEPE & 1.07 & 1.02 & 1.09 & 0.98 \\
\hline KOZLUK & 1.03 & 1.44 & 1.48 & 0.72 \\
\hline KURTALAN & 0.91 & 1.04 & 0.95 & 1.01 \\
\hline MALATYA & 1.09 & 1.04 & 1.13 & 0.97 \\
\hline MARDIN & 1 & 1 & 1.00 & 1 \\
\hline MERSIN & 0.93 & 1.04 & 0.97 & 0.94 \\
\hline MIDYAT & 0.97 & 1 & 0.97 & 1.03 \\
\hline MUS & 0.99 & 1.11 & 1.10 & 0.91 \\
\hline NIZIP & 1.01 & 1 & 1.01 & 0.99 \\
\hline NUSAYBIN & 1 & 1 & 1.00 & 1 \\
\hline PATNOS & 0.96 & 1.11 & 1.07 & 0.91 \\
\hline REYHANLI & 0.97 & 0.98 & 0.95 & 1.03 \\
\hline SAHINBEYI & 1 & 1.02 & 1.02 & 1 \\
\hline SEHITKAMIL & 1.36 & 1.01 & 1.37 & 0.76 \\
\hline SIIRT & 1 & 0.92 & 0.92 & 1 \\
\hline SILVAN & 0.96 & 1.15 & 1.10 & 0.87 \\
\hline SIRNAK & 0.93 & 1.04 & 0.97 & 0.99 \\
\hline SIVAS & 0.92 & 1 & 0.92 & 1.01 \\
\hline SIVEREK & 0.95 & 1.05 & 1.00 & 0.95 \\
\hline SURUC & 1.04 & 1.62 & 1.68 & 0.62 \\
\hline URFA & 1.07 & 1.04 & 1.11 & 0.99 \\
\hline VAN & 0.99 & 0.99 & 0.98 & 1.02 \\
\hline
\end{tabular}




\begin{tabular}{|c|c|c|c|c|c|}
\hline Distributors & MI & TC (\%) & MI (\%) & EC (\%) & SEC (\%) \\
\hline ADANA & 0.90 & -4.08 & -10.56 & -6.48 & 2.96 \\
\hline ADIYAMAN & 1.07 & -6.19 & 6.35 & 12.54 & 3.92 \\
\hline AFSIN & 0.99 & 1.98 & -1.11 & -3.09 & -4.08 \\
\hline AGRI & 0.97 & 0.00 & -3.15 & -3.15 & 1.98 \\
\hline AKCAKALE & 1.05 & -5.13 & 4.40 & 9.53 & 9.53 \\
\hline ANTAKYA & 0.99 & -4.08 & -1.17 & 2.92 & 3.92 \\
\hline ARABAN & 1.04 & -107.88 & 3.96 & 111.84 & 1.98 \\
\hline BATMAN & 1.10 & -3.05 & 9.44 & 12.49 & 2.96 \\
\hline BINGOL & 0.94 & 1.98 & -6.18 & -8.16 & -4.08 \\
\hline BIRECIK & 0.98 & -17.44 & -1.89 & 15.55 & 16.55 \\
\hline BISMIL & 1.02 & -32.85 & 1.59 & 34.44 & 36.46 \\
\hline BITLIS & 1.01 & -15.08 & 0.75 & 15.84 & 14.84 \\
\hline BULANIK & 0.97 & -32.85 & -2.57 & 30.28 & 36.46 \\
\hline CERMIK & 0.99 & -13.93 & -0.82 & 13.10 & 18.23 \\
\hline CIZRE & 0.86 & -3.05 & -14.70 & -11.65 & -11.65 \\
\hline DIYARBAKIR & 1.15 & 0.00 & 13.98 & 13.98 & 0.00 \\
\hline ELAZIG & 1.06 & -8.34 & 6.12 & 14.46 & 7.70 \\
\hline ELBISTAN & 1.01 & 1.00 & 0.96 & -0.04 & 1.98 \\
\hline ERGANI & 0.95 & -9.43 & -4.63 & 4.80 & 19.89 \\
\hline ERZURUM & 0.95 & -17.44 & -4.97 & 12.47 & 16.55 \\
\hline GAZIANTEP & 1.16 & 0.00 & 14.84 & 14.84 & 0.00 \\
\hline HAKKARI & 0.97 & 1.00 & -3.09 & -4.08 & 0.00 \\
\hline HANI & 0.99 & 1.98 & -1.11 & -3.09 & -4.08 \\
\hline HILVAN & 0.97 & -11.65 & -3.13 & 8.53 & 19.06 \\
\hline ISKENDERUN & 0.95 & 1.98 & -4.63 & -6.61 & 3.92 \\
\hline K.MARAS & 0.97 & -18.63 & -3.07 & 15.56 & 23.90 \\
\hline KAHTA & 0.97 & 0.00 & -3.15 & -3.15 & 1.98 \\
\hline KARS & 1.03 & 0.00 & 2.96 & 2.96 & 2.96 \\
\hline KILIS & 1.01 & 0.00 & 1.00 & 1.00 & 1.00 \\
\hline KIZILTEPE & 1.07 & -2.02 & 6.73 & 8.75 & 1.98 \\
\hline KOZLUK & 1.07 & -32.85 & 6.57 & 39.42 & 36.46 \\
\hline KURTALAN & 0.96 & 1.00 & -4.51 & -5.51 & 3.92 \\
\hline MALATYA & 1.10 & -3.05 & 9.49 & 12.54 & 3.92 \\
\hline MARDIN & 1.00 & 0.00 & 0.00 & 0.00 & 0.00 \\
\hline MERSIN & 0.91 & -6.19 & -9.52 & -3.33 & 3.92 \\
\hline MIDYAT & 1.00 & 2.96 & -0.09 & -3.05 & 0.00 \\
\hline MUS & 1.00 & -9.43 & -0.00 & 9.43 & 10.44 \\
\hline NIZIP & 1.00 & -1.01 & -0.01 & 1.00 & 0.00 \\
\hline NUSAYBIN & 1.00 & 0.00 & 0.00 & 0.00 & 0.00 \\
\hline PATNOS & 0.97 & -9.43 & -3.08 & 6.35 & 10.44 \\
\hline REYHANLI & 0.98 & 2.96 & -2.11 & -5.07 & -2.02 \\
\hline SAHINBEYI & 1.02 & 0.00 & 1.98 & 1.98 & 1.98 \\
\hline SEHITKAMIL & 1.04 & -27.44 & 4.30 & 31.74 & 1.00 \\
\hline SIIRT & 0.92 & 0.00 & -8.34 & -8.34 & -8.34 \\
\hline SILVAN & 0.96 & -13.93 & -4.03 & 9.89 & 13.98 \\
\hline SIRNAK & 0.96 & -1.01 & -4.34 & -3.33 & 3.92 \\
\hline SIVAS & 0.93 & 1.00 & -7.34 & -8.34 & 0.00 \\
\hline SIVEREK & 0.95 & -5.13 & -5.38 & -0.25 & 4.88 \\
\hline SURUC & 1.04 & -47.80 & 4.36 & 52.16 & 48.24 \\
\hline URFA & 1.10 & -1.01 & 9.68 & 10.69 & 3.92 \\
\hline VAN & 1.00 & 1.98 & -0.03 & -2.01 & -1.01 \\
\hline
\end{tabular}


